\title{
Driving Product Sales Performance using Product Prelaunch LiNguistics ANALYTIC APPROACH
}

\author{
Winnie $\mathrm{Ng}^{1}$ and Vincent $\mathrm{Cho}^{2}$ \\ ${ }^{1}$ Faculty of Business, The Hong Kong Polytechnic University, Hong Kong \\ ${ }^{2}$ Department of Management and Marketing, \\ The Hong Kong Polytechnic University, Hong Kong
}

\begin{abstract}
This paper uses a natural linguistics analytic approach, by studying product prelaunch events' script, to investigate the determinants of driving the product sales. This research contributes to the theoretical framework of identifying the customer values which impact the product sales. Moreover, we investigate how product sales be driven by the optimism attitude and affective forecasting, which are vocal during product prelease events. Through the pilot study of analysing the essential words, which represent the underlying customer values from the script of Apple Inc. product prelaunch events, we found that product functional and experiential/ hedonic of customer values drive product sales. Induced affective forecasting message negatively moderated the impact of cost/ sacrifices values on product sales. In addition to the theoretical framework contributions, this research provides practical guidelines of how to shape the product prelaunch speech to maximize the sales of the to-be-released products.
\end{abstract}

\section{KEYWORDS}

Product Preannouncement, Product Sales, Signalling, Communications, Speech Recognition

\section{INTRODUCTION}

"To me, marketing is about values"..... Steve Jobs - CEO \& Co-Founder of Apple Inc.

Rewinding back to 2007 summer, around June, a scene in New York City is so impactful bringing global awareness and unforgettable - thousands of wide-ranging ages public queuing in line with the anticipating looks outside a New York City store. They were all lined up for a product that would be released an hour after - Apple@ $\odot$ iPhone. What factors and how are these customers' expectations driven from product desire to product sales? This would be tribute by the increasing trend of product prelaunch events to be organized by firms, especially in high-tech industry; enabling with multi-media experience; to demonstrate and showcase their new products to be released. On one hand, we see the trend that firms are investing more and more to support the product prelaunch or product prerelease to market the products. For instance, Apple Inc. drew a lot of media coverage with countless headlines in 2015, which dramatically increased advertising budget by $50 \%$ exceeding US\$1 Billion [1]. On the other hand, the attractiveness of prelaunch events to the audience is also expanding which can be demonstrated by the shorten time of tickets to be sold out, as reflected in The Apple Worldwide Developers Conference ("WWDC"). WWDC is a conference held annually by Apple Inc. to showcase its software and technologies for software developers. WWDC began in 1987 and it now becomes Apple's primary media event of the year and regularly sold out, and sold out very quickly. Until 2007, the 
number of attendees varied between 2,000 and 4,200. While from WWDC 2007; the time with Steve Jobs as Apple Inc.'s CEO; noted that there were more than 5,000 attendees. The WWDC events held from 2008 to 2015 were capped, and sold out at 5,000 attendees (5,200 including special attendees). WWDC 2018 had grown to 6,000 attendees from 77 countries, including 350 scholarship recipients [2].

Driving by this upward phenomenon, this research study is to review the phenomenon of the increase of product prelaunch events for firms to prerelease and its effectiveness of marketing the to-be-released products. This research draws attention to the theory of customer values, which drive product sales. In addition, we further investigate how customers' optimism psychology would impact their purchase decision.

When customers buying products, as a general phenomenon, customers are evaluating and assessing the values they can get from what they pay for. Customer value is what they "get" (the gained benefits) relative to what they are willing to "give-in" (e.g. costs, pay, time or sacrifices) [3]. There has been extant of literature researching customer values frameworks with various views on value dimensions. Back to 2003, Ulaga [4] researched the customer values applying to manufacturers and suppliers relationships suggesting eight different dimensions of the customer values, which focuses on manufacturer-supplier relationships. Further to 2007, Smith and Colgate [5] identifies four types of value that an organization can create, especially from marketing managers' perspective, to derive marketing strategy to capture customer values. It consists of i) Functional/ Instrumental, ii) Experiential/ Hedonic iii) Symbolic/Expressive and iv) Cost/Sacrifice Values. This is widely referred and quoted as the essential framework for customer values given its balanced and wider adoption by the industry. Further on, O'Cass and Ngo in 2011 [6] studied from firms and customers' perspective about what firms provide and add value to response to customers looking for in the marketplace. It stipulates i) Performance, ii) Pricing, iii) Relationship, and iv) Co-creation values. The above three frameworks are mainly empirical research and theoretical frameworks about customer values. The practical impact on customer purchase decision, product sales performance, firm values, etc. can be further studied and explored.

One essential core of marketing is to achieve personal, organizational and societal objectives by creating superior customer values as stated in the above three frameworks for the target market segments with a sustainable strategy. The second essential one is to plan how all the enhanced values throughout the customer value chain can be conveyed to the target audience through effective communications.

From Eades and Kear's [7] model of systemic drivers of value perception, communications alignment is an important driver (or process) right before entering sales execution drivers stages which lead to final customers' decision to buy.

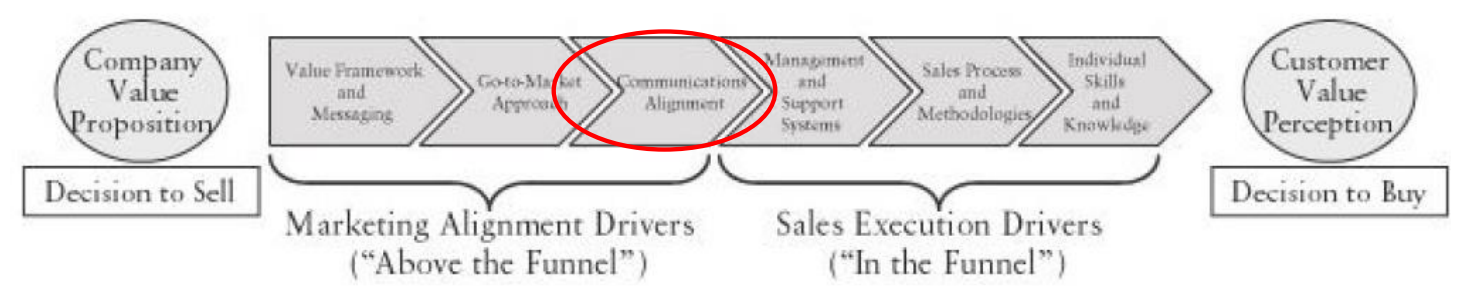

Figure 1. Systemic Drivers of Value Perception [7]

With numerous research around key success factors in new product launch, what are determinants of new product launch success, product launch strategies, new product announcement and 
corresponding market reactions. Benedetto [8] identifies successful launches relate to perceived superior coordination among marketing research, sales force, distribution, promotion, R\&D and engineering. Also in this research, timing of the launch, i.e. when the launch should be conducted, to preempt competition and to notify the customers is just as important to other successful launch factors.

Marketing strategy and related marketing activities are important aligning to the product development and product life cycle. Matikainen et al. [9] identifies key determinants for new product launch by studying along the product life cycle, examining the role, the relationship among various phases of the innovation diffusion in learning and promoting customer acceptance [10]. In studying across the product life cycle, product advantage and relationship marketing activities contribute in getting customers' acceptance in the early phase of product life cycle. Thus this sheds the light of relationship activities should be considered in early phase of product life cycle so as to achieve higher target market acceptance.

In regards of the relationship activities, this relates to the extant literature research about new product announcement and related strategies. Extant literature suggests that the firms use information relating to their innovations, in the form of new products, to enhance their image [11]. Thus, firms find it beneficial to communicate their new product development activities to internal and external audiences in advance of new product introduction [12], [13]. A lot of previous research has studied the effectiveness of product annoucement as a communications and signalling strategy in various product types. Indeed, sustainable firms often own a lot of product portfolio with various stages of product development that can be early-stage innovation, advanced-stage new product concepts and market-ready new products, etc. It is important with guidance referenced in determining what stage(s) of product cycle or portfolio should be appropriate to disclose to external, to alert target customers, preempt competition to bring the most benefits (product sales performance) to firms. Kim and Mazumdar [14] studied through the firms organizing trade shows to investigate the effects of demonstrations of different product development stages on the firms' values. The results showed that preannoucement of demonstrated concepts with products approaching their launch had the strongest positive impact to firms' values, followed by early-stage concept (named debuts products), and then market-ready new products. This sheds the light on the important of investing the product prelaunch events to drive product sales performance, relating to the product development stages impact.

Dahlén, Thorbjørnsen and Sjödin [15] investigated consumer response to advertising for future, to-be-released products. Their findings demonstrated that firms and advertisers or marketers should seriously consider prerelease advertising over market-ready or existing product advertising. The research draws on the consumer psychology relating to the optimism bias, positive uncertainty and affective (mis)forecasting, which collectively namely "Nextopia" effect. Nextopia is a general belief among consumers that the next product will always be the better one. Dahlén, Thorbjørnsen and Sjödin [15] stated prerelease advertising could possibly present an opportunity to position the product as superior, creating interest and thus purchase intentions. Moreover, prerelease advertising might have also created over the ever-increasing competitive landscape of existing products.

While nowadays, grand product prelaunch events are organized to attract overwhelmed audience to increase brand awareness and media exposure, especially for those high-tech products or innovative products (e.g. gadgets, innovated automotive). However little has been known about how effective of product prelaunch events can drive and impact product sales. This study is first and foremost research on the impact of a widely adopted framework of customer values [5] to product sales. This study also leverages on the research of Kim and Mazumdar [14] about 
maximizing the firm values of preannounced product concept. Moreover, how "Nextopia" would impact the product sales will be addressed.

In analyzing product prelaunch events, we use the linguistics approach to study about the firms' spokespersons' scripts in conveying different messages about customer values which are induced by consumer psychology. In sum, this research focus on driving product sales through studying customer values and "Nextopia" effect. Besides, we further propose the study 2 through experiment design by understanding customers' perspective on preannouncement activities on related sales.

Our findings can offer additional insights for the spokespersons when preparing the product prelaunch events' scripts and wordings in signaling and delivering information about the firms' innovations, products information to the market, which drives product sales. This research contributes by providing practical guidance of which customer value(s) of the framework is impactful to the customers' purchase intention. Additionally, by analyzing both the induced customer psychology effect by firms, as well as consumers' response to product prelaunch events, this research identifies the "Nextopia" effect driving the product sales.

Following sections will be presented in this paper, literature review, theories and research conceptual framework. Research model will be described, and discussions of the findings. A further study from consumers' perspective will be debriefed, ending with the limitations and conclusion.

\section{LITERATURE REVIEW}

There is a commonly held view that new product launch is a significant drive for firms' growth. In Eades and Kear [7], systematic drivers such as go-to-market approach, communications alignment, etc. are depicted to demonstrate how a company decides to sell with its proposition of product values to enhance the perception of customer values, and to motivate customers' decision to buy. From dominant theories of marketing, customer value refers to customers' perceptions of what they receive, in return for what they sacrifice [3]. There are two aspects to customer value: i) desired value and perceived value [16]. Desired value refers to what a customer desires in a product or service. Perceived value is the benefit a customer receives from a product or service based on its usage or consumption. Customer values propositions are formulated by assessing the current market offerings, identifying what customers want, and then developing a product, service, or solution that meets the market need as mentioned by Anderson [17]. Customer values propositions are firms' preemptive values that create the customers' values. An effective customer value proposition can attract new customers, increase customer satisfaction, which provides a competitive advantage for the firm. 


\subsection{Customer Values propositions}

There are divergent views on the customer values propositions as listed below:

\begin{tabular}{|c|c|c|}
\hline$\underline{\text { Reference }}$ & $\underline{\text { Customer values propositions }}$ & $\underline{\text { Application dimensions }}$ \\
\hline Ulaga, 2003 [4] & $\begin{array}{ll}\text { - } & \text { Product Quality } \\
\text { - } & \text { Service Support } \\
\text { - } & \text { Delivery Performance } \\
\text { - } & \text { Supplier Know-how } \\
\text { - } & \text { Time to Market } \\
\text { - } & \text { Personal Interaction } \\
\text { - } & \text { Price and Process Costs }\end{array}$ & $\begin{array}{l}\text { - Apply to manufacturer- } \\
\text { supplier relationships }\end{array}$ \\
\hline Smith and Colgate, 2007 [5] & $\begin{array}{l}\text { - Functional/ Instrumental } \\
\text { Value } \\
\text { - Experiential/ Hedonic } \\
\text { Value } \\
\text { - Symbolic/ Expressive } \\
\text { Value } \\
\text { - Cost/Sacrifice Value }\end{array}$ & $\begin{array}{l}\text { Marketing managers } \\
\text { perspective that identifies } \\
\text { types of value and the } \\
\text { organization to create this } \\
\text { types of value }\end{array}$ \\
\hline O’Cass and Ngo, 2011 [6] & $\begin{array}{ll}\text { - } & \text { Performance Value } \\
\text { - } & \text { Pricing Value } \\
\text { - } & \text { Co-Creationship Value } \\
\end{array}$ & $\begin{array}{l}\text { - Value offering from a } \\
\text { firm's view } \\
\text { - Interpretation of what } \\
\text { customers are looking for } \\
\text { in the marketplace }\end{array}$ \\
\hline
\end{tabular}

There has been an extant of literatures about customer values propositions. In Smith and Colgate [5], drawing on, integrating, and extending previous conceptual foundations, a customer values framework is proposed. This framework identifies four major types of value that can be created by organizations - i) Functional/ Instrumental value, ii) Experiential/ Hedonic value, iii) Symbolic/ Expressive value and iv) Cost/ Sacrifice value. This suggests a "balance scorecard" approach to assess the customer values creation. Smith and Colgate [5] provide a comprehensive framework [18] for a complete view on the customer values creation that managers, executives, and leaders can implement to distinguish themselves from competitors. An entrepreneurial firm must deliver the most important values to its customers. Meanwhile, researchers acknowledge that understanding the customer values' creation is central for marketing strategy [18].

\subsection{Entrepreneur's Advantages}

Entrepreneurial firms focus their scarce resources on the creation of values (e.g., cost, use value, emotional value and social value) [5] that matter most to customers. They market their capabilities in terms of those aspects their customers can associate with and preempting competition. Thus, we further look into how an entrepreneurial firm can deliver values along the dimensions that matter most to its customers. The challenge for suppliers is not only recognizing what values to create or what the benefits are, but also to deliver values to customers. Referencing Shanker [19], the table below is a collection of views from the extant literature pool on customer values' creation and delivery. It shows how entrepreneurs can use their understanding of customer values to their advantages. 
Understanding of Customer Value Concept Points of values that matter to customers [17]

Dimensions along which value is perceived [16] Customer's desired needs change over time [20] Customer feedback [16]
The Entrepreneur's Advantage Creating customer values proposition with a resonating focus [17]

Competing based on points of values other than just its cost Delivering values proactively by anticipating changes in customer's desired needs [20] Improving values propositions of existing products and services

\subsection{Signalling strategies on new product preannouncements}

Associating with the understanding of customer values concept, firms derive the communications strategies to selectively disclose information about their product development activities to the outside world to attract customers, preempt competition, and signal investors about potential changes in firm value [21], [22], [23]. A stream of literature on new product preannouncements typically examines their benefits and pitfalls. Previous research has investigated the effectiveness of such signalling strategies in the contexts of announcements of research-and-development (R\&D) investments and early-stage innovation projects. (e.g. Sood, Ashish \& Tellis [24]), preannouncements of new products in early stages of development (e.g. Sorescu, Shankar \& Kushwaha [25]) and announcements of new products that are commercially available in the market (e.g. Chaney, Devinney \& Winer [26]). Preannouncements of new products would build customer demand and possibly signal near-term incremental revenue potential [26].

In terms of strategic perspective, Bayus, Jain \& Rao [21] found dominant firms with low product development costs using a preannouncement strategy to create an entry barrier to preempt competition. Eliashberg \& Robertson [22] researched that the impending release of a preannounced new product might also lead consumers to postpone purchase until the actual introduction. On the negative side, product preannouncements may alert competitors, giving them the opportunity to "leapfrog" the preannouncing firm's product [23].

However, there is a diverse view on the financial implication of preannouncement strategy. Mishra \& Bhabra [28] found weak positive effects of stock return firm value especially when stock market ignores bluffs or easily reversible announcements. Sorescu, Shankar \& Kushwaha [25] utilize a market-signalling framework [29] and demonstrate that new product preannouncements signal the market about future earning potentials, thereby positively affecting the firm values. The effect is stronger when the information in the preannouncement is specific, when the information is updated, and when the credibility of the firm is high.

In an early study by Eddy \& Saunders [30] that utilized small samples and weekly stock returns. They found that new product announcements have little or no effect on stock returns. However, in a more comprehensive analysis involving various industries, several hundred firms and over thousands of new products, Chaney, Devinney \& Winer [26] found a negative effect of the number of introduction announcements on cumulative abnormal returns in some industries, indicating that the less the number of announcements, the greater the increase in firm valuations. Sorescu, Chandy \& Prabhu [31] suggested that technological and market breakthrough new products have positive effects on firm values. Moreover, using data for 20,000 new consumer packaged goods, Sorescu \& Spanjol [32] proved that breakthrough new products added firm values. 
In sum, new product launches have been shown to signal firms' internal innovations to the market. The effectiveness of the signalling strategies has been shown to increase when the announced product involves advancement of product features or technologies, and when signals are credible. We extend existing literature by focusing product sales in terms of units sold, which is a new dimension to measure the performance of a firm in an objective manner.

Regarding the signalling strategies, previous literature focus on studying the tactics on advertisement (e.g. [8], [15]) or tradeshow [14]. Kim \& Mazumdar, investigated the effects of demonstrating early-stage innovations, more-advanced-stage new product concepts, and marketready new products on firm value in trade shows. They demonstrated that conceptual launch had the strongest positive effect, followed by early-stage concepts demonstrated for the first time (called product debuts), and then market-ready new products. The research also found the support of trade show locations mediated these effects.

To further demonstrate how consumers response to advertisements for future and, to-be-released products, Dahlén, Thorbjørnsen \& Sjödin [15] did an experimental study of customers' responses to car advertisements to investigate how advertising the same product before versus after release. Their second experimental study is followed to extend the findings with mineral water advertisements for both familiar and unfamiliar brands. These researches shed the effect of customer purchase behaviour called "Nextopia" - that is, a general belief among consumers that the next product will always be the better one than currently owned.

\section{4. "Nextopia"}

In [15], it is found that future-frame advertising has positive effects, and marketers need to consider prelaunch advertising. The research is based on the notion of "Nextopia", which covers three interrelated concepts in consumer psychology, namely i) the optimistic bias, ii) positive uncertainty and iii) affective forecasting.

Firstly, in the aspect of optimistic bias, research finds that in general, people tend to be unrealistically optimistic about their future (e.g. [33], [34], [35]). This optimistic bias stems from firstly the positive biased beliefs about the future, and secondly fantasies depicting future events. For example, consumers tend to believe that their next mobile phone will be better than what they are currently having.

In regards to the positive uncertainty, recent research indicates that when key message and, promotion message of an event are positively framed, uncertainty may yield more pleasure than certainty (e.g. [36], [37]). Lee and Qiu's [36] study in the context of lucky draws and loyalty reward programs have shown people do derive pleasure from uncertainty. Similar effects have been uncovered like movie trailers, where spectators are left uncertain about the specific content and the ending of the movie [37]. This uncertainty is prominent in consumer towards forthcoming new product. The more radically new a product is perceived, the greater are the promised benefits, features, but also the perceived uncertainty [38].

Thirdly, literature on affective forecasting suggests that consumers tend to overestimate the impact and duration of future positive events [39]. In particular, consumers may experience affective forecasting because consumers fairly incorporate largely positive beliefs at the moment of choice [40]. Thus, when people consider their next gadget(s), they not only overestimate the impact and duration of the happiness they will experience when using the new gadget, but also tend to forget how quickly that happiness wore off when they bought their previous gadget, especially in technological, innovative products. 
Building on these three consumer psychology concepts, Dahlén, Thorbjørnsen \& Sjödin [15], adopt the findings to the context of marketing communications, and indicate advertising for a future product to produce greater (positive) uncertainty than advertising for a current product. Prerelease advertising could possibly also present an opportunity to position the product as superior, creating interest and purchase intentions in the challenging and ever-increasing competitive landscape of current products.

\subsection{Research Gap}

Based on the above stated extant literatures of customer values propositions and signaling strategies tactics, there is limited research delineates how future advertising, broadly extending to marketing communications activities that may play the significant role in customer values propositions signaling tactical strategies benefiting the firm gains. In this regard, this research not just extends the extant literature of firm values or stock returns by adding the product sales aspect, but also provides an empirical research of the propositions framework impact evidently to product sales performance.

Additionally, in Dahlén, Thorbjørnsen, \& Sjödin [15], the positive effect of "Nextopia" was supported by experimental study with objects dominantly students. Our current study takes on two perspectives on Nextopia: a corporate preannouncement on new product launch and real customers' perception on the preannouncement. Referring earlier section, the extant literature research in the area about product announcements and product preannouncements correlate to firm values or financial return in the context of trade shows and advertisement. Research on the effects of product preannouncements in the context of product prelaunch events, and correlating to actual product sales is not yet explored. We extend the research stream in marketing communications by focusing the context of product prelaunch events, and closing the gap of financial impact by product sales.

This research contributes to provide additional theoretical framework of product sales performance be impacted by the customer values propositions framework and possibly enhanced by "Nextopia" psychology effect in studying from both firms' interpretations and consumers' reactions' perspective. In addition, practically, this research provides insights for an effective product prelaunch or communications activities in driving product sales performance based on both objective live data and target audience' reactions.

\section{THEORIES}

\subsection{Signalling Theories}

Much corporate innovation takes place within the firms, where there is information asymmetry between investors, markets and the firms. Through product preannouncements, firms signal the market about incremental revenue drive from new products that have been produced from the demonstrated concepts [25]. The information asymmetry between the firms and the external markets is the greatest for the product prelaunch events. At the same time, there are severe information asymmetries between product launching companies and customers because the product launching firms possess more information about the new product to be available in the future. Information asymmetry problems are mitigated by conveying useful information [29]. Also, the signalling framework suggests that firms should select the level, the form to convey the signal that maximized the difference between the driving benefits of signalling and the cost of signalling. Signalling theory is frequently cited in the entrepreneur management literature [41], finance, marketing literature [42]. Kirmani \& Roa describe the process by which the signaller the firm sends a signal that is received by the potential customers - receiver; within a certain 
signalling environment. In this process, signals and the signalling environment determine the receiver's evaluation of the signallers' quality or value, which applies and matters to potential customers' desire to purchase intention. In the product prelaunch events, the two primary elements of signalling strategy involve: i) conveying the firm's internal innovations with the help of a mix of demonstrated concept, product features and solutions to the future, ii) the consistent of the product prelaunch event message with the firms' signalling goals in driving product sales, and growth.

In product prelaunch phase, consumers lack reliable information on the product for their decision of purchase. This research leverages signalling theory [29] as a theoretical framework to purport product sales performance directly driven by customer values proposition through product prelaunch event to communicate the signals to receiver - the target and potential consumers.

\section{2. "Nextopia" Customer Psychology}

In [15], Dahlén, Thorbjørnsen, \& Sjödin investigate consumer response to advertising for future, to-be-released products over current products drawing on the recent consumer psychology that research on the positive uncertainty, optimism bias and affective forecasting. Dahlén, Thorbjørnsen, \& Sjödin [15] demonstrate the consumers' positive bias in reacting to the next products' advertisement, increasing the product brand preference and desire to purchase with the effect namely "Nextopia".

"Nextopia" effects on previous research conducted on three interrelated concepts in consumer psychology, namely i) Positive Uncertainty, ii) Optimistic Bias and iii) Affective Forecasting. Established consumers psychology drives customers' behaviour, especially determining consumers' decision or desire to purchase.

In general, although it seems like people may believe that most of them prefer certainty over uncertainty, the recent research suggests that when positively framed (e.g. in most of the case of advertising or launching events), uncertainty may actually yield more leisure than certainty based on the "pleasure paradox", which is introduced by Wilson et al. [37]. When faced with uncertainty associated with a positive event, consumers appear to experience greater and longerlasting positive feelings [36], the referred statement as - Positive Uncertainty.

Optimism bias is a form of self-positivity bias and implies that people are overly positive about their own future demonstrating this bias in Zhang, Fishbach, and Dhar [43]. Through the research, the study shows that the research target systematically overestimate their future commitment and achievements. People tends to believe to behave ideally in their future and thus overestimate positively to future products to pursue.

Affective forecasting is the meaning that people generally anticipate or forecast of how their decisions and choices will make them feel [44]. To a large extent, people's choices are based on their forecast feelings [45]. Affective forecasting has a certain positive effect on purchase intention because people generally overestimate the magnitude and the duration of the future purchase feelings they actually get. People beliver that the happiness and satisfaction, e.g. buying an anticipated, long-waited bag or gadgets, will be thrilled and longlasting which these feelings play a major part in the purchase decision.

These psychology backup the consumers reaction on attending product prelaunch events, reading the prereleased products advertisement or media write-up [15]. 


\section{CONCEPTUAL FRAMEWORK}

\subsection{Customer values framework for product launch}

For product debut, as consumers lacking of reliable information on the product, it is quite the greatest asymmetric of information between the signal receivers and the firms. Firms riding on the asymmetric of information operationalize customer-facing processes to deliver values to customers, to drive how entrepreneurs utilizing their understanding of customer values to maximize their return advantage [19]. This refers to an entrepreneurial consumer values propositions. These prepositions are formulated by assessing the current market offerings, competitions, identifying what potential consumers or target market want, and to develop the product, solutions or services that meet the market need [17]. According to the framework of customer values as proposed by Smith and Colgate [5], it delineates the major types of values driving customer desire to purchase. The framework composes four major types of value, each has below key facets driving customers' desire to purchase:

Functional/ instrumental value is concerned with the extent to which a product (or good or service) has desired characteristics to fulfil target customers' desired goals. As suggested by Woodruff [16], there are three key facets of function/ instrumental value related to features, performance and outcomes \& benefits. As customers are always looking for products or solutions or services to fulfil their goals or solve their problems, we purport:

Hypothesis 1: Product functional/ instrumental value directly increases product sales performance representing by product sales in terms of unit sold

Experiential/ hedonic value is concerned with the extent to which a product creates appropriate experiences, feelings and emotions for the customer. Referencing online video games, more participants and gamers would purchase or join the video games if more excitements, challenges can be provided in the game. Or turning into high-tech innovative products, users tend to favour a more personalized and user-friendly interface products considering the ease of use and product usage. Thus we purport:

Hypothesis 2: Product experiential/ hedonic value directly increases product sales performance representing by product sales in terms of unit sold

Symbolic/ expressive value is concerned with the extent to which customers attach or associate psychological meaning to a product, e.g. luxury goods, appealing to customer's self-concepts and self-worth. Think about what the colour of the mobile phone you bought last time, think about what colours range of the mobile phone companies they offer, and some companies price differently of different product colour, for example, gold, this drives the products somehow to bring or represent different social status or image for the customers. Thus we posit:

Hypothesis 3: Product symbolic/ expressive value directly increases product sales performance representing by product sales in terms of unit sold

Cost/ sacrifice value is concerned with the transaction costs that involve in the purchase, ownership, the use of product, opportunity cost, convenience, psychological or relational costs. The cost or sacrifice that would be associated with the use, the purchase, and the change has to make or invest to the product desire to purchase. Thus consumers usually favour to continue with the same brand of product or service to purchase with previous acceptable same brand product experience except there is significant pricing gap in offsetting the possible sacrificing related costs. We posit: 
Hypothesis 4: The lower the product cost/ sacrifice value, the higher the directly increases of product sales performance representing by product sales in terms of unit sold

\subsection{Moderating role of the product prelaunch event in firms' perspective}

Referencing Kim \& Mazumdar [14], it analyses 3 stages of product development stages delivering the firms' abnormal returns. From the research, it demonstrates product initial concepts which is in preparation potential launch induces the strongest positive effect to firms' abnormal returns, followed by early-stage concept (i.e. product debuts), and the least the market-ready new products.

In consideration of setting the appropriate customer values propositions in maximizing the firms' benefits in return and to drive the success or growing product sales performance, firms may strategically select different marketing communications in which to demonstrate the products' concepts, features, also considering different product stages. In Kim \& Mazumdar [14], it compares "early-stage concepts (debuts)", "Advanced-stage concepts (concepts)" and "Marketready products" effect on abnormal returns, with tradeshow mediation effect and location-based argument behind tradeshow. The summarized results support that the first demonstrations of early-stage product concepts generate a positive and significant increase in firm value, also when these are presented in tradeshows in the firm's home country, but not else region. For advancedstage concepts products, significant increase in abnormal returns of firm stocks is generated and are further enhanced by the firm's history of successful conversion of concepts to commercialization. There is also positive effect presented in trade show venues in the organization's home country as well as located in a different country. While market-ready products demonstrated in a trade show have a weak or no effect on abnormal firm's returns.

Referencing the cited research, new product launches have been shown to signal firm's internal products innovations to external market and mediated by communications activities (e.g. trade shows) [14]. The effectiveness of the signalling strategies, applying to marketing communications strategies, has been shown increasing for products debuts or product preannouncements. We extend the research stream by proposing the moderating effect products prelaunch event in driving the products sales unit volume, based on the signalling environment in the context of high-technology products prelaunch events.

Previous research mostly studied in consumers' reactions about what impact and derive the customers' purchase intention. Combining the signalling theories with information asymmetry, and entrepreneurs' desire to understand the potential consumers' psychology, applying to their signalling strategies, in maximizing their products sales returns and benefits, our research framework addresses the moderating effect of "Nextopia" in the signalling strategies in firms' product launching setting.

This demonstrates in product prelaunch events that organizations usually drive engaging and positive market and products outlook. Think about how many times you fantasy the desire figure with the diet you plan to set in a week, the number of times of exercise in a week you plan, or the ideal look you admire when you sign up the fitness club membership. The recent studies on new product introductions suggest that consumers tend to underestimate any problems or difficulties and are optimistic about their future in adopting new products [46]. And in Tanner and Carlson [34] concluded that even if individuals can identify the possible obstacles, or problems, or certain degree of optimism in estimating their future, individuals tend to unwilling to adjust and lower the optimism estimates. Thus Dahlén, Thorbjørnsen \& Sjödin [15] suggest "Nextopia" advertising would evoke an optimism bias prompting consumers to view their use of the product through a more positive lens. Consumers also tend to overestimate the value and benefit of future products. If firms in conveying their signals in product prelaunch events enhances positive 
optimism bias messages, this will possibly produce more favourable, optimistic feelings for potential consumers and enhances the future product sales. And by scripting the favourable bias message in the prelaunch communications events, the relationships of four types of customer values propositions impact the product sales performance will be moderated as:

Hypothesis 5: Firms' induced optimistic attitude messages moderate positively the relationship between (a) functional/ instrumental value (b) experiential/ hedonic value (c) symbolic/ expressive (d) and moderate negatively cost/ sacrifice value to product sales performance representing by the products sales in terms of unit sold

Forecast feelings tend to guide consumers' actions, influence consumers' evaluations of the prelaunching product brand, and thus most notably, consumers' purchase intentions. With the affective forecasting which means the general people's anticipation or forecast of how their decisions and choices will make them feel [44]. As when firms inflate the consumers' anticipated enjoyment of the future product, purchase intentions should be increased. Additionally, the anticipated enjoyment should favorably affect the products' perceive quality that induces the general expectation as future products are better than present ones. Thus as we hypothesize with firms induced positive affective forecasting message, the relationship of the customer values propositions with consumers' purchase intention will be moderated as:

Hypothesis 6: Firms' induced positive affective forecasting messages moderate positively the relationship between (a) functional/ instrumental value (b) experiential/ hedonic value (c) symbolic/ expressive (d) and moderate negatively cost/ sacrifice value to product sales performance representing by the products sales in terms of unit sold

Positive uncertainty may not apply from firms' perspective through the message scripted in product prelaunch events. It is because products to-be-released are definite and introduced which varies from the gambling or lucky draw setting. On the other hand, this will be considered in second hypothesis conceptual framework about customers' response perspective as the prelaunched products in context are similar to movie trailer setting [37] that consumers may evoke more thoughts to the future products through prelaunch events.

In summary, below Figure. 2, presents the conceptual framework of the proposed research hypothesis of customer value propositions direct effects to product sales and the firms' induced "Nextopia" effect moderates the customer value propositions to increase the consumers decision to buy - which will be directly reflected by the number of goods sold that is the dependent variable in the proposed model 1: Product Sales

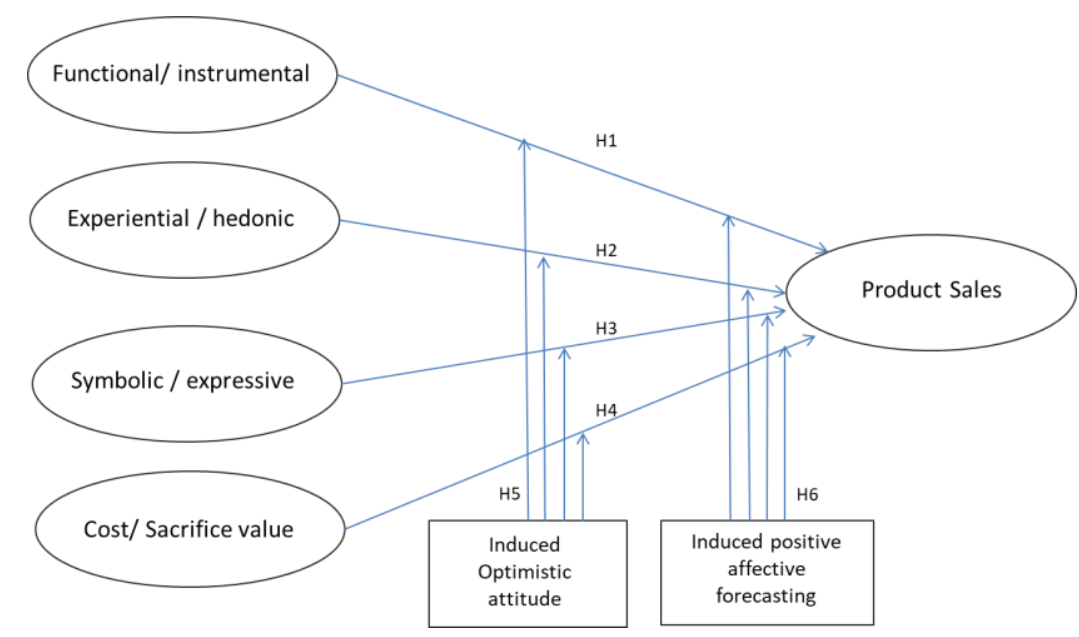

Figure 2. Proposed conceptual framework 01 - firms' perspective 
The above framework focuses on driving and understand what determinants drive customers' purchase intentions, which are reflected by product sales performance objectively from firms' perspective.

The section below describes another framework addressing the same issue from the customers' perspective.

\subsection{Moderating role of the product prelaunch event in customers psychology reactions perspective}

Recent research [36], [37] indicate that when messages (e.g. products' information, customer values propositions) are positively framed, uncertainty may yield more pleasure than certainty, which is based and dubbed from "pleasure paradox". This demonstrates through entering lucky draw event, gambling and movie trailer. Wilson et al. [37] found that winners in a lucky draw experienced more positive feelings when they were not immediately told which prize they got. Lee and Qiu [36] state when people face with uncertainty associated with a positive event, or an event whih is framed positively, consumers appear to experience greater and longer positive feelings. Thus, prelaunch a product in future time frame may evoke more thoughts and possible speculations about the to-be-released products. We believe this future uncertainty in positive setting will drive below proposed moderating effect through customers' perceptions and reactions:

Hypothesis 7: Greater the consumers' evokes thoughts relating to future uncertainty moderate positively the relationship between (a) functional/ instrumental value (b) experiential/ hedonic value (c) symbolic/ expressive (d) and moderate negatively cost/ sacrifice value to consumers' purchase intention

Further on, the below hypothesis referencing the previous sections' reasonings and based on the customers behaviour and reaction demonstrated in [15], it is believed that customers' reactions driving by "Nextopia" psychology would increase their purchase intention through product prelease activities, which is the research context of product prelaunch events convey the customers values propositions framework key elements. Thus we hypothesis:

Hypothesis 8: More consumers' optimistic attitude moderate positively the relationship between (a) functional/ instrumental value (b) experiential/ hedonic value (c) symbolic/ expressive (d) and moderate negatively cost/ sacrifice value to consumers' purchase intention

Hypothesis 9: More consumers' positive forecasting feeling moderate positively the relationship between (a) functional/ instrumental value (b) experiential/ hedonic value (c) symbolic/ expressive (d) and moderate negatively cost/ sacrifice value to consumers' purchase intention

Below Figure. 3, presents the conceptual framework of the proposed research hypothesis of customers' reactions by "Nextopia" psychology moderation effect of impacting the customer values propositions to increase the consumers' intentions to buy - which will be measured by the experiment study of customers' purchase intention. 


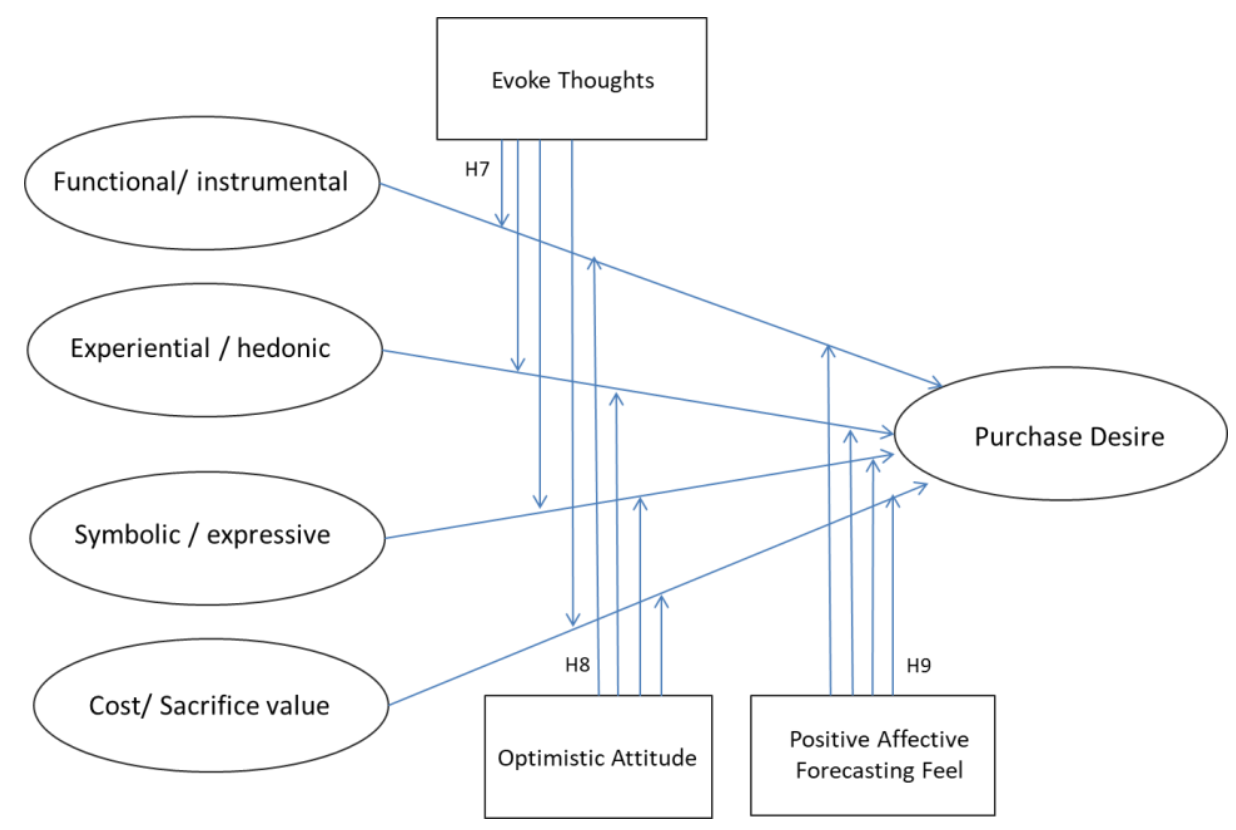

Figure 3. Proposed conceptual framework 02 - consumers' reaction perspective

\section{RESEARCH DESIGN AND METHODOLOGY}

\subsection{Data and Empirical Context}

The hypotheses are tested in the context of the high-tech consumer electronics industry. The consumer electronics industry is particularly interesting to this research proposal because signalling strategies has been shown to increase when the announced products involves significant breakthrough of technology, especially beneficial to innovative products [14], where mobile phones, tablets are one of the fast-moving innovative products. Secondly, data of similar products have been used in the context of new product introductions and preannouncement [21] and [25], in respect of high-tech industries, new technologies are developed and applied rapidly, such that firms have to always keep the stakeholders and target market informed of the forthcoming innovations and product roadmaps. This can be especially demonstrated in this proposal of research data. Apple Inc. holds different products types prelaunch annually and periodically, which gives a stable and wide long enough time span for the proposed hypothesis data research. Additionally, Apple Inc. usually begins preannouncing its products several months (e.g. three to six months) before its release and actual purchase occasion available in the market. Thus this phenomenon is a perfect example and suggestion of "Nextopia advertising" demonstration - marketing future products before the release of sales.

\subsubsection{Methodology}

To test the proposed hypotheses, we conducted a pilot study and propose a further study. Pilot study used a linguistics approach and algorithm to study and analysis the model direct effects and how two of the "Nextopia" phenomenal in our hypothesis moderates the product sales through analysing the product prelaunch events script.

Secondly, to further test the second proposed conceptual framework of understanding the impact of consumers' purchase intentions or desire from consumers' reactions by "Nextopia" psychology, Study 2 is proposed to use an experimental design to measure the hypothesized moderating effects to the purchase intention. 


\subsection{Pilot Study - Contemporary linguistics approach:}

The conducted pilot study is to analysis the longitudinal data of Apple Inc. product prelaunch events and pre-products released between 2006 to 2019 to investigate i) The model direct effects and ii) the moderating effects of firms' induced optimistic attitude and firms' induced affective forecasting messages to the relationships of the four customer values chain. There are two main reasons we analysed Apple Inc. product prelaunch events. Firstly, "Nextopia" psychological behaviour is influencing future decision buying. This is especially relevant and phenomenal for industries with short life cycles in which new products are regularly and relatively frequent to introduce. New products in these industries (e.g. music or new technological devices such as the iPad) often experience a peak in demand that occurs immediately after the prelaunch of the product. In addition, electronic industries (e.g. mobile phone, wearables, computing gadgets) are highly competitive and dynamic. This requires differentiated product and organization values to customers that can demonstrate the customer values frameworks and how an organization behaves in "Nextopia" psychological effects to moderate the consumer buying behaviour. Secondly, Apple Inc. product prelaunch events have been held periodically and with sufficient longitudinal history of data, also include variety of products in each product prelaunch, which gives sufficient data points and data continuity. This can enhance confidence level of the statistical assumptions of unbias, random of the data by statistical analysis tools.

\subsubsection{Data collection}

English script of the Apple Inc. product prelaunch events from 2006 to 2019 are collected from the website - https://singjupost.com/, which prior script accuracy is cross-checked against the Apple Inc. Podcasts. There are in total 16 product launch events recorded, demonstrating and involving variety of Apple Inc. products ranged from iPad, iPad mini, Apple TV, Apple Watch, Apple mobile phone - iPhone with about 51 unique product models spanned the years.

Independent variables and moderators

The collected product prelaunch transcripts are firstly divided into different product segments by recognizing the product name in the introduction header session. The presenter speech is then populated into the independent variables, moderators score by counting the words related and based on the psychosocial wordings stipulated in Smith and Colgate [5] customer values frameworks survey and Dahlén, Thorbjørnsen \& Sjödin [15]'s customers reactions survey. We then concluded the word counting marks of each product in each product prelaunch event and segregate the type of representing customers' values and induced customers' behaviours with below criterias:

1. Functional / Instrumental Value: Action verbs (usually linked with potential features), Noun: features / function, +er words. E.g. faster, etc., Words like faster / access / camera

2. Experiential / Hedonic Value: Personal Pronouns: I/ you / your/ yourself, Sensational/ senses: advance, experience

3. Symbolic/ Expressive Value: Image / status / personal: Stunning, coloring

4. Cost/ Sacrifice Value: It/ product + functional words: allow/ alert, Adjective relating to needs: e.g. track/ need

5. Induced Optimistic Attitude: Positive adjective: e.g. Awesome/ beautifully/...

6. Induced Affective forecasting: Verbs showing affection: e.g. Want / love/ believe Product Sales

For the product sales data, we propose to refer to product unit sales by product type published by Apple Inc. yearly and CIR (Consumer Insights Research), which is a market recognizable 
research institute with all repository data of the researched Apple Inc. products of the proposed research by product, by model and quarterly product sales in terms of unit sold. For product sales figures, no. of units sold accumulating after one (1) year of product launch. Giachetti \& Marchi [47] is proposed to analyse to capture the "shadow diffusion" effect of innovation diffusion theory; with one year data which is close to the product life-cycle and to control with previous version product sales data after the pre-product launch effect.

Secondly, due to various product types and product sales data, normalization for the linear regression analysis has been performed on the product sales data by following logic. We worked out the ratio comparison of each different type of products (e.g. accumulated one year apple watch sales units is 40 times then Apple Mac units in the past year). We used one baselined products, and re-adjusted the else product types according to the one-year product sales units ratio to normalize for statistical analysis.

\section{DISCUSSION}

\subsection{Pilot Study}

We adopted R software to perform the linear regression analysis. We first tested if the data can pass assumption for linear regression. Our results showed data passed the assumption test. Thus data was viable to go with linear regression analysis. With the hypothesized direct and moderation effect. We performed 3 stages of models analysis. 1) First we tested all the direct effects:

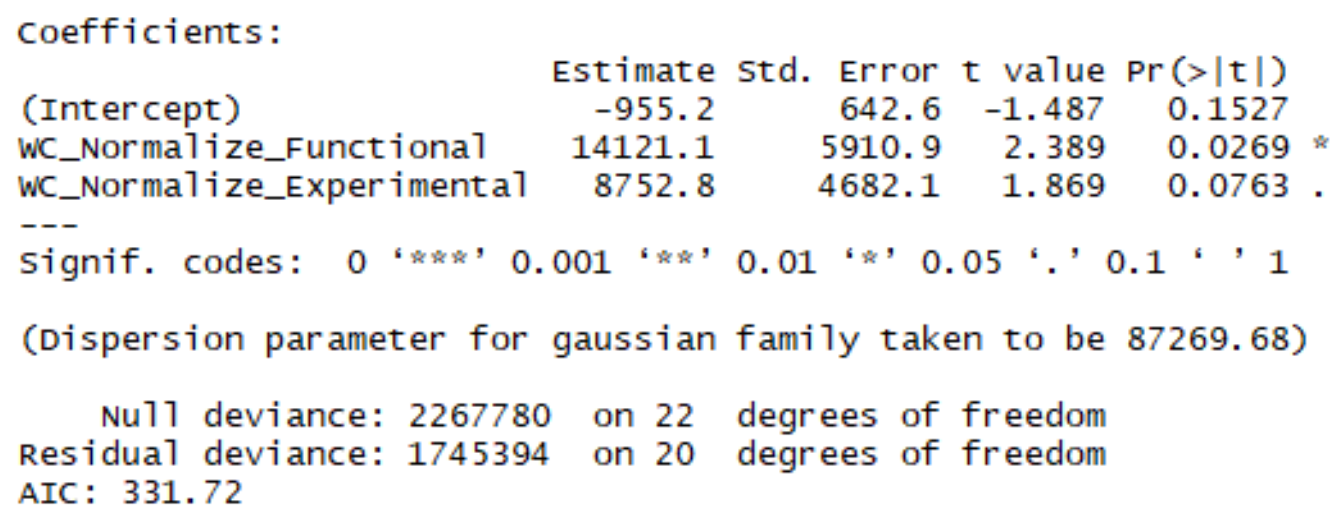

Figure 4. Pilot Study Model 1 Result

Figure 4 stipulated the hypothesis model 01 direct effect. From the result, customer values framework - Functional resulted P value at 0.0269 which showed the most significant impact to product units sales. Followed by customer values framework - Experiential resulted $\mathrm{P}$ value at 0.0763 , which showed barely significant in the linear regression statistics. Thus in respect of conceptual model 01, Hypothesis 1 is supported and Hypothesis 2 is supported with less significant. Hypothesis 3 nor Hypothesis 4 are not supported.

We then ran model 2) to test any direct impact of proposed moderators of conceptual framework 01 . 


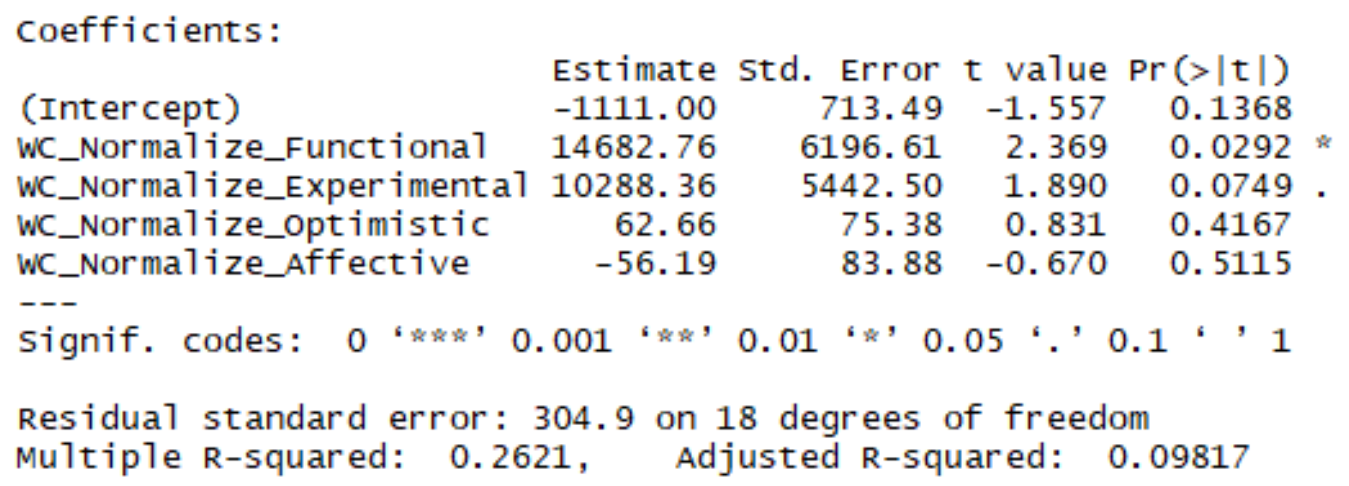

Figure 5. Pilot Study Model 2 Result

By adding induced optimistic attitude word counts and induced affecting forecasting word counts in the linear regression test, no significant direct effect is shown in Figure 4. Thus there is no direct impact effect of proposed moderators in conceptual framework 01 to product unit sold. Lastly, we ran the model 3) to test the moderation effect to the four (4) customer values framework values. Figure 6. depicts the statistical test analysis result:

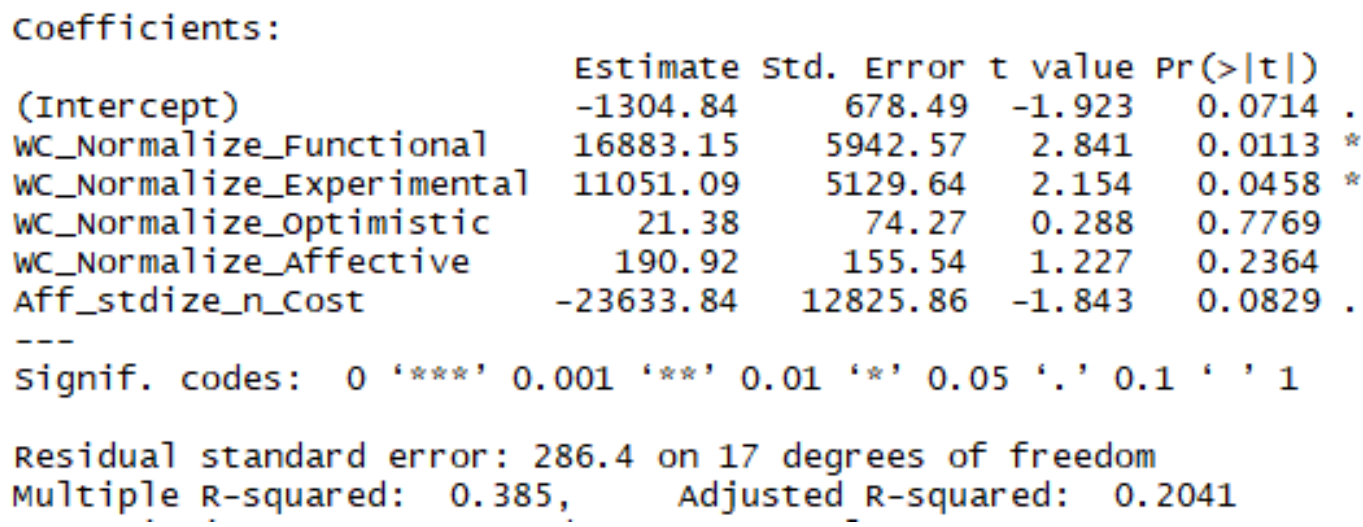

Figure 6. Pilot Study Model 3 Result

The adjusted R-square of Model 3 is 0.2041 , which is in a reasonable range of linear regression test of data analysis reliability. With the moderators added, direct effect of Functional and direct effect of Experiential remains significant, while induced affective forecasting moderates the relationship of cost to product unit sales relationship with $\mathrm{P}$ value at 0.0829 and negative coefficient. This presents induced affective forecasting negatively moderates the cost / sacrifices customer values framework values to product unit sold. Overall, there is no significant statistical moderation impact of induced optimistic attitude to the product unit sold. Thus hypothesis 5 is not supported, while hypothesis 6 is partially supported with $6 \mathrm{a}, \mathrm{b}, \mathrm{c}$ not supported but $6 \mathrm{~d}$ in regards of cost / sacrifices values is supported.

\subsection{Further study - Study 2: Experimental Design}

To collect further the positive uncertainty moderation effect and to minimize the common method bias and survey with consumer psychology behaviour, Study 2 - an experimental design study is proposed. Considering four independent variables and three moderators, 300 customer studies are proposed to collect. 
We propose to randomly assign the volunteer participants to different groups of research products (e.g. iPad, Apple Watch, etc.). We will play the pre-product launch event of the clip related to their assigned product group. Upon watching, will distribute the questionnaire adopting the rating and survey item based on [15] experimental design and the consumers purchase intention referencing the same measurement and design in [15], i.e. any change of immediate purchasing intention.

After completing the questionnaire, it is proposed to ask what they thought the purpose of the research was.

\subsubsection{Survey Sample Questions}

\section{Evoke Thoughts}

- To record their thoughts to the product before the play, and record after the play to compare the no. of thought and rate "positive", "neutral" or "negative" thoughts

We propose following survey questions to be measured on a 7-point Likert-type scale:

Optimistic Attitude

OA1: e.g. I feel favourable to the demonstrated product (Pleasant, Good, Pleased)

Positive Affective Forecasting Feel

AF1: e.g. I feel excited to the demonstrated product (Satisfied, Anticipated, Thrilled)

Purchase Intention

PI1: e.g. I am interested to the demonstrated product (Will try out, want to buy, will purchase)

\section{Limitations AND CONCLUSIONS}

This study contributes the theoretical framework on customer values and how the value drivers affect product sales. In addition, through pilot study adopting the linguistics approach, it demonstrates the direct effect of product functional and experiential features drive product sales. In addition, this research further contributes to the "Nextopia" customer psychology in which affective forecasting moderation effect is supported. Practically, this research provides the guidance about how marketing communications events can be shaped and scripted to drive future released product sales growth.

Despite its merits, this study has its limitations. The pilot study of this research adopted single brand products. Thus data points could be a constraint while the assumption behind linear regression analysis was tested and passed. Customer preference or brand spill-over effect could be one of the unobservable underlying factors for decision-to-buy, especially in developed and repeated buying markets, although this is considered to be eliminated by one of the independent variable - cost/ sacrifice value (e.g. minimizing personal time investment in getting new product verse switching brand). Further research can consider various product brands of the same product type. Also, further research can extend to different industries for a comprehensive picture of customer values and prerelease impact.

\section{ACKNOWLEDGEMENTS}

The authors would like to thank the anonymous reviewers, session chair and participants in the session! 


\section{REFERENCES}

[1] Jacqueline (2018) https://medium.com/seedx-digital-marketing-guru/why-apple-spends-18-billion-on-advertising-38d3940270bf

[2] Apple Worldwide Developers Conference published data

[3] V. A. Zeithaml, "Consumer Perceptions of Price, Quality, and Value: A Means-End Model and Synthesis of Evidence," Journal of Marketing, vol. 52, no. 3, pp. 2-22, 1988.

[4] W. Ulaga, "Capturing value creation in business relationships: A customer perspective," Industrial Marketing Management, vol. 32, no. 8, pp. 677-693, 2003.

[5] J. B. Smith and M. Colgate, "Customer Value Creation: A Practical Framework," Journal of Marketing Theory and Practice, vol. 15, no. 1, pp. 7-23, 2007 [Online]. Available: http://www.tandfonline.com/doi/abs/10.2753/MTP1069-6679150101

[6] A. O'Cass and L. V. Ngo, "Examining the Firm's Value Creation Process: A Managerial Perspective of the Firm's Value Offering Strategy and Performance," British Journal of Management, vol. 22, no. 4, pp. 646-671, 2011

[7] K. M. Eades and R. E. Kear, The solution-centric organization. New York: McGraw-Hill, 2006.

[8] C. A. Di Benedetto, "Identifying the key success factors in new product launch," The Journal of Product Innovation Management, vol. 16, no. 6, pp. 530-544, 1999.

[9] M. Matikainen, T. Rajalahti, M. Peltoniemi, P. Parvinen, and A. Juppo, "Determinants of New Product Launch Success in the Pharmaceutical Industry," Journal of Pharmaceutical Innovation, vol. 10, no. 2, pp. 175-189, 2015.

[10] E. M. Rogers, Diffusion of innovations, 5th ed.. New York: Free Press, 2003.

[11] O. Heil and T. S. Robertson, "Toward a theory of competitive market signaling: A research agenda," Strategic Management Journal, vol. 12, no. 6, pp. 403-418, 1991.

[12] S. Rabino and T. E. Moore, "Managing new-product announcements in the computer industry," Industrial Marketing Management, vol. 18, no. 1, pp. 35-43, 1989.

[13] B. Lilly and R. Walters, "Toward a Model of New Product Preannouncement Timing," Journal of Product Innovation Management, vol. 14, no. 1, pp. 4-20, 1997.

[14] T. Kim and T. Mazumdar, "Product Concept Demonstrations in Trade Shows and Firm Value," Journal of Marketing, vol. 80, no. 4, pp. 90-108, 2016.

[15] M. Dahlén, H. Thorbjørnsen, and H. Sjödin, "A Taste of "Nextopia"," Journal of Advertising, vol. 40, no. 4, pp. 33-44, 2011 [Online]. Available: http://www.tandfonline.com/doi/abs/10.2753/JOA0091-3367400403

[16] R. Woodruff, "Customer value: The next source for competitive advantage," Journal of the Academy of Marketing Science, vol. 25, no. 2, pp. 139-153, 1997.

[17] Anderson and Narus, "Customer Value Propositions in Business Markets," Harvard Business Review, vol. 84, no. 3, pp. 90-99, 2006 [Online]. Available: http://search.proquest.com/docview/227835040/ 
[18] Aparna Shanker, "A Customer Value Creation Framework for Businesses That Generate Revenue with Open Source Software," Technology Innovation Management Review, no. March 2012: Technology Entrepreneurship, pp. 18-22, 2012 [Online]. Available: https://doaj.org/article/575737f9f00f454e97404558cda5768c

[19] A. Shanker, "Q\&A. What Is Customer Value and How Do You Deliver It?," Technology Innovation Management Review, vol. 2, no. 2, pp. 32-33, 2012 [Online]. Available: http://search.proquest.com/docview/1614474449/

[20] Flint, Daniel J., Woodruff, Robert B., and Gardial, Sarah Fisher, "Exploring the phenomenon of customers' desired value change in a business-to-business context.," Journal of Marketing, vol. 66, no. 4, pp. 102-117, 2002.

[21] B. L. Bayus, S. Jain, and A. G. Rao, "Truth or Consequences: An Analysis of Vaporware and New Product Announcements," Journal of Marketing Research, vol. 38, no. 1, pp. 3-13, 2001

[22] J. Eliashberg and T. S. Robertson, "New Product Preannouncing Behavior: A Market Signaling Study," Journal of Marketing Research, vol. 25, no. 3, pp. 282-292, 1988.

[23] T. S. Robertson, J. Eliashberg, and T. Rymon, "New Product Announcement Signals and Incumbent Reactions," Journal of Marketing, vol. 59, no. 3, pp. 1-15, 1995.

[24] "Do Innovations Really Pay Off? Total Stock Market Returns to Innovation," Marketing Science, vol. 28, no. 3, pp. 442-456, 2009.

[25] A. Sorescu, Shankar, Venkatesh, and Kushwaha, Tarun, "New Product Preannouncement and Shareholder Value: Don't Make Promises You Can't Keep” Journal of marketing research, vol. 44, no. 3, pp. 468-489, 2007.

[26] Chaney, Paul K., Devinney, Timothy M., and Winer, Russell S., "The impact of new product introductions on the market value of firms. (includes appendix)," The Journal of Business, vol. 64, no. 4, pp. 573-610, 1991.

[27] K. B. Hendricks and V. R. Singhal, "Delays in New Product Introductions and the Market Value of the Firm: The Consequences of Being Late to the Market," Management Science, vol. 43, no. 4, pp. 422-436, 1997.

[28] D. Prasad Mishra and H. S. Bhabra, "Assessing the economic worth of new product preannouncement signals: theory and empirical evidence," Journal of Product \& Brand Management, vol. 10, no. 2, pp. 75-93, 2001.

[29] M. Spence, "Job Market Signaling,” The Quarterly Journal of Economics, vol. 87, no. 3, pp. 355$374,1973$.

[30] A. R. Eddy and G. B. Saunders, "NEW PRODUCT ANNOUNCEMENTS AND STOCK PRICES,” Decision Sciences, vol. 11, no. 1, pp. 90-97, 1980.

[31] Sorescu, Alina B., Chandy, Rajesh K., and Prabhu, Jaideep C., "Sources and financial consequences of radical innovation: insights from pharmaceuticals.," Journal of Marketing, vol. 67, no. 4, pp. 82-102, 2003.

[32] B. Sorescu and J. Spanjol, "Innovation's Effect on Firm Value and Risk: Insights from Consumer Packaged Goods," Journal of Marketing, vol. 72, no. 2, pp. 114-132, 2008 [Online]. Available: http://search.proquest.com/docview/227807599/

[33] F. P. McKenna, "It won't happen to me: Unrealistic optimism or illusion of control?," British Journal of Psychology, vol. 84, no. 1, pp. 39-50, 1993. 
[34] R. Tanner, Carlson, Kurt, Bettman, Jim, Larrick, Rick, and Sanna, Larry, "Unrealistically optimistic consumers: A selective hypothesis testing account for optimism in predictions of future behavior," ProQuest Dissertations Publishing, 2008 [Online]. Available: http://search.proquest.com/docview/304635590/

[35] N. D. Weinstein, "Unrealistic optimism about future life events," Journal of Personality and Social Psychology, vol. 39, no. 5, pp. 806-820, 1980.

[36] Y. Lee and C. Qiu, "When Uncertainty Brings Pleasure: The Role of Prospect Imageability and Mental Imagery,” Journal of Consumer Research, vol. 36, no. 4, pp. 624-633.

[37] T. D. Wilson, D. B. Centerbar, D. A. Kermer, and D. T. Gilbert, "The Pleasures of Uncertainty: Prolonging Positive Moods in Ways People Do Not Anticipate," Journal of Personality and Social Psychology, vol. 88, no. 1, pp. 5-21, 2005.

[38] Alexander, David L., Lynch, John G., and Qing Wang, "As time goes by: do cold feet follow warm intentions for really new versus incrementally new products?(Report)," Journal of Marketing Research, vol. 45, no. 3, pp. 307-319, 2008.

[39] J. E. J. Ebert, D. T. Gilbert, and T. D. Wilson, "Forecasting and Backcasting: Predicting the Impact of Events on the Future," vol. 36, no. 3, pp. 353-366, 2009.

[40] J. Wang, N. Novemsky, and R. Dhar, "Anticipating Adaptation to Products," in Advances in Consumer Research, 2009, vol. 36 [Online]. Available: http://search.proquest.com/docview/1807738875/

[41] Lester, Richard H., Certo, S. Trevis, Dalton, Catherine M., Dalton, Dan R., and Cannella, Albert A., "Initial Public Offering Investor Valuations: An Examination of Top Management Team Prestige and Environmental Uncertainty," Journal of Small Business Management, vol. 44, no. 1, pp. 1-26, 2006.

[42] A. Kirmani and A. R. Rao, "No Pain, No Gain: A Critical Review of the Literature on Signaling Unobservable Product Quality,” Journal of Marketing, vol. 64, no. 2, pp. 66-79, 2000.

[43] Y. Zhang, A. Fishbach, and R. Dhar, "When Thinking Beats Doing: The Role of Optimistic Expectations in Goal-Based Choice," Journal of Consumer Research, vol. 34, no. 4, pp. 567-578.

[44] Patrick, Vanessa M., Macinnis, Deborah J., and Park, C. Whan, "Not as happy as I thought I'd be? Affective misforecasting and product evaluations.," Journal of Consumer Research, vol. 33, no. 4, pp. 479-489, 2007.

[45] B. Shiv and J. Huber, "The Impact of Anticipating Satisfaction on Consumer Choice," Journal of Consumer Research, vol. 27, no. 2, pp. 202-216, 2000.

[46] Alexander, David L., Lynch, John G., and Qing Wang, "As time goes by: do cold feet follow warm intentions for really new versus incrementally new products?(Report)," Journal of Marketing Research, vol. 45, no. 3, pp. 307-319, 2008.

[47] C. Giachetti and G. Marchi, "Evolution of firms' product strategy over the life cycle of technology-based industries: A case study of the global mobile phone industry, 1980-2009," Business History, vol. 52, no. 7, pp. 1123-1150, 2010 [Online]. Available: http://www.tandfonline.com/doi/abs/10.1080/00076791.2010.523464 


\section{Authors}

\section{Winnie Ng}

Ms. $\mathrm{Ng}$ is a professional business leader with in-depth experience of full spectrum from business strategy planning to diversified marketing activities, translate marketing plan into actions that drives business growth with leading strategic initiatives and results, has been in senior leadership role with years of proven track record in multinational companies with global experience. Also she is an invited guest speaker for digital marketing, ROI, organization development and sustainability

\section{Dr. Vincent Cho}

Dr. Cho currently researches on "m-commerce technology adoption" and "health care information system adoption". He is also specialized on data mining, stock index forecasting, database marketing, yield management and e-commerce infrastructure and strategy. His research papers are published on various international journals including Information \& Management, Journal of Computer information Systems, Expert Systems, Knowledge and Information Systems, Journal of Computational Intelligence in Finance, Journal of Hospitality and Tourism Research, International Journal of Hospitality Management, International Journal of Tourism Research, Annals of

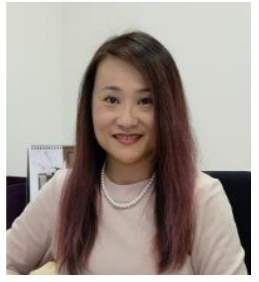
Tourism Research. Before joining the university, he had several years of experience in systems development in some prestige international consulting firms. He is also interested in consultancy works. 